\title{
Association of a beta-2 adrenoceptor (ADRB2) gene variant with a blunted in vivo lipolysis and fat oxidation
}

Citation for published version (APA):

Jocken, J. W., Blaak, E. E., Schiffelers, S. L. H., Arner, P., van Baak, M. A., \& Saris, W. H. (2007). Association of a beta-2 adrenoceptor (ADRB2) gene variant with a blunted in vivo lipolysis and fat oxidation. International Journal of Obesity, 31(5), 813-819. https://doi.org/10.1038/sj.ijo.0803499

Document status and date:

Published: 01/01/2007

DOI:

10.1038/sj.ijo.0803499

Document Version:

Publisher's PDF, also known as Version of record

Please check the document version of this publication:

- A submitted manuscript is the version of the article upon submission and before peer-review. There can be important differences between the submitted version and the official published version of record.

People interested in the research are advised to contact the author for the final version of the publication, or visit the DOI to the publisher's website.

- The final author version and the galley proof are versions of the publication after peer review.

- The final published version features the final layout of the paper including the volume, issue and page numbers.

Link to publication

\footnotetext{
General rights rights.

- You may freely distribute the URL identifying the publication in the public portal. please follow below link for the End User Agreement:

www.umlib.nl/taverne-license

Take down policy

If you believe that this document breaches copyright please contact us at:

repository@maastrichtuniversity.nl

providing details and we will investigate your claim.
}

Copyright and moral rights for the publications made accessible in the public portal are retained by the authors and/or other copyright owners and it is a condition of accessing publications that users recognise and abide by the legal requirements associated with these

- Users may download and print one copy of any publication from the public portal for the purpose of private study or research.

- You may not further distribute the material or use it for any profit-making activity or commercial gain

If the publication is distributed under the terms of Article $25 \mathrm{fa}$ of the Dutch Copyright Act, indicated by the "Taverne" license above, 


\title{
Association of a beta-2 adrenoceptor (ADRB2) gene variant with a blunted in vivo lipolysis and fat oxidation
}

\author{
JWE Jocken $^{1}$, EE Blaak ${ }^{1}$, S Schiffelers ${ }^{1}$, P Arner $^{2}$, MA van Baak $^{1}$ and WHM Saris ${ }^{1}$ \\ ${ }^{1}$ Department of Human Biology, Nutrition and Toxicology Research Institute Maastricht, Maastricht University, Maastricht, \\ The Netherlands and ${ }^{2}$ Department of Medicine, Karolinska Institute, Huddinge University Hospital, Stockholm, Sweden
}

Background and aims: Obesity is associated with a blunted $\beta$-adrenoceptor-mediated lipolysis and fat oxidation. We investigated whether polymorphisms in codon 16, 27 and 164 of the $\beta_{2}$-adrenoceptor gene (ADRB2) and exon 10 of the G protein $\beta_{3}$-subunit gene (GNB3) are associated with alterations in in vivo lipolysis and fat oxidation.

Design and methods: Sixty-five male and 43 female overweight and obese subjects (body mass index (BMI) range: $26.1-48.4 \mathrm{~kg} / \mathrm{m}^{2}$ ) were included. Energy expenditure (EE), respiratory quotient (RQ), circulating free fatty acid (FFA) and glycerol levels were determined after stepwise infusion of increasing doses of the non-selective $\beta$-agonist isoprenaline (ISO). Results: In women, the Arg16 allele of the ADRB2 gene was associated with a blunted increase in circulating FFA, glycerol and a decreased fat oxidation during ISO stimulation. In men, the Arg16 allele was significantly associated with a blunted increase in FFA but not in glycerol or fat oxidation.

Conclusion: These results suggest that genetic variation in the ADRB2 gene is associated with disturbances in in vivo $\beta$-adrenoceptor-mediated lipolysis and fat oxidation during $\beta$-adrenergic stimulation in overweight and obese subjects; these effects are influenced by gene-gender interactions.

International Journal of Obesity (2007) 31, 813-819. doi:10.1038/sj.ijo.0803499; published online 28 November 2006

Keywords: lipolysis; fat oxidation; single-nucleotide polymorphism; ADRB2 gene; GNB3 gene

\section{Introduction}

Obesity is characterized by increased circulating free fatty acid (FFA) concentrations and increased triglyceride (TG) storage within adipose tissue. In vivo studies have shown that the development or maintenance of increased adipose tissue stores might be promoted by a blunted lipolytic response and fat oxidation after $\beta$-adrenergic stimulation or exercise in obese or obese type 2 diabetic subjects. ${ }^{1-4}$ This blunted $\beta$-adrenoceptor-mediated lipolysis and fat oxidation persisted after weight reduction, indicating that this disturbance may be an early, even primary factor, in the development or maintenance of increased adipose stores. ${ }^{1}$ There are indications that the blunted $\beta$-adrenergically mediated lipolysis in obesity may be related to an impaired function or a reduced number of adipocyte beta-2 $\left(\beta_{2}\right)$ adrenoceptors. ${ }^{5,6}$ $\beta_{2}$-Adrenoceptors are stimulatory G-protein-coupled $\left(\mathrm{G}_{\mathrm{s}}\right)$ receptors. The $\beta_{2}$-adrenoceptor (ADRB2) gene is encoded by

Correspondence: Dr JWE Jocken, Department of Human Biology, Maastricht University, PO Box 616, 6200 MD, Maastricht, The Netherlands.

E-mail: J.Jocken@hb.unimaas.nl

Received 17 November 2005; revised 11 August 2006; accepted 15 August 2006; published online 28 November 2006 an intronless gene on chromosome 5q31-q32. ${ }^{7,8}$ Several polymorphisms of the human ADRB2 gene have been described. ${ }^{9,10}$ Among these, three common single-nucleotide polymorphisms (SNPs) result in the substitution of an amino acid. One is located at codon 16, substituting arginine for glycine (Arg16Gly). The other one is located at codon 27, substituting glutamic acid for glutamine (Gln27Glu). Both variants are located in the extracellular amino-terminal region of the receptor and alter cellular trafficking and desensitization of the receptor. ${ }^{11}$ Previous studies have reported associations between codons 16 and 27 polymorphisms and obesity, insulin resistance and hypertension. ${ }^{12-22}$ Finally, the substitution of isoleucine for threonine at codon 164 (Thr164Ile), in the receptor transmembrane-spanning domains, alters agonist binding and decreases coupling of the $\mathrm{G}_{\mathrm{s}}$ protein to the receptor. ${ }^{23,24}$ There is evidence from in vitro studies that some of these receptor variants might be important for catecholamine-induced adipocyte lipolysis in humans. ${ }^{16,25}$

Furthermore, polymorphisms in $\mathrm{G}$ proteins involved in catecholamine signaling may alter corresponding receptor and hormone function. Recently, a common polymorphism substituting a cytosine for a thymine at position 825 (C825T) in exon 10 of the G-Protein $\beta_{3}$-subunit (GNB3) gene 
(chromosome 12p13), coding an isoform of the $\mathrm{G}$ protein $\beta$ subunit $\left(\mathrm{G} \beta_{3}\right)$, has been identified. ${ }^{26} \mathrm{G}_{\mathrm{s}}$ deficiency is also observed in obesity and the C825T polymorphism is associated with obesity and hypertension in both white and non-white populations. ${ }^{27-34}$ In vitro studies indicated that the $825 \mathrm{~T}$ variant of $\mathrm{G} \beta_{3}$ in its homozygous form was associated with a decreased amount of $\mathrm{G} \beta_{3}$ in fat cells, thereby inhibiting signaling through $\beta_{1^{-}}, \beta_{2^{-}}$and $\alpha_{2}$-adrenoceptors, resulting in decreased catecholamine action and blunted lipolysis in isolated subcutaneous adipocytes of male and female obese subjects. ${ }^{35}$

Thus, there are indications that polymorphisms in the $A D R B 2$ gene and the GNB3 gene may be related to an impaired in vitro lipolytic response. So far, however, few in vivo lipolysis studies on these polymorphisms have been performed. For this reason, the present study investigated the effect of genetic variation in the ADRB2 and the GNB3 gene on in vivo lipolysis and fat oxidation in overweight and obese subjects.

\section{Methods}

\section{Subjects}

The study group consisted of 108 overweight and obese (BMI range: $26.1-48.4 \mathrm{~kg} / \mathrm{m}^{2}$ ) subjects $(43 \mathrm{~F} / 65 \mathrm{M})$. Twentyfour overweight subjects (BMI between 25 and $29.9 \mathrm{~kg} / \mathrm{m}^{2}$; $11 \mathrm{~F} / 13 \mathrm{M}$ ) and 84 obese subjects (BMI $>29.9 \mathrm{~kg} / \mathrm{m}^{2}$; $32 \mathrm{~F} / 52 \mathrm{M})$ were included. The basic selection criteria were age $20-50$ years and $\mathrm{BMI}>25 \mathrm{~kg} / \mathrm{m}^{2}$. Exclusion criteria were weight change $>3 \mathrm{~kg}$ within 3 months before the study started, drug-treated hypertension, diabetes or hyperlipidemia, thyroid disease, surgically treated obesity, pregnancy, alcohol or drug abuse and participation in other simultaneous ongoing trials. All subjects were recruited by means of an advertisement in a local newspaper. All subjects were in good health as assessed by medical history and physical examination and were not taking any medication. A normal resting electrocardiogram (ECG) and blood pressure were a prerequisite for participation. The study protocol was reviewed and approved by the Medical Ethical Review Committee of Maastricht University. The subjects were informed in detail about the investigation and their consent was obtained before participating in the study.

\section{Anthropometric measurements}

Body weight was determined on an electronic scale, accurate to $0.1 \mathrm{~kg}$. Waist and hip circumference measurements to the nearest $1 \mathrm{~cm}$ were made with the subjects standing upright. BMI was calculated as body weight in kilograms divided by squared height in meters. Body density was obtained by underwater weighing with residual pulmonary volume measurement by the helium dilution method (Volugraph 2000, Mijnhardt) and was converted to percent body fat using the equation of Siri. ${ }^{36}$ Fat mass (FM) and fat-free mass (FFM) were calculated from the percent body fat and body weight.

\section{Study design}

The subjects arrived at the laboratory at 0800 after an overnight fast (of at least $12 \mathrm{~h}$ ) by car or public transport. They were studied while resting supine on a comfortable bed in a room kept at $23-25^{\circ} \mathrm{C}$. At the beginning of the experiment, a catheter was inserted into a forearm vein for blood sampling. A second catheter was inserted into the contralateral arm for infusion of the non-selective $\beta$-agonist isoprenaline (ISO). Thirty minutes after insertion of the catheters, the measurement protocol started. Energy expenditure and substrate oxidation were measured during the entire period with an open-circuit ventilated hood system. After $30 \mathrm{~min}$, blood was sampled for baseline measurements and genetic analysis. Following the 30-min baseline period, ISO infusion started at increasing concentrations of 6,12 and $24 \mathrm{ng} \cdot \mathrm{kg} \mathrm{FFM}^{-1} \cdot \mathrm{min}^{-1}$, each dose for $30 \mathrm{~min}$. At the end of each infusion period, venous blood samples were taken, centrifuged and stored at $-80^{\circ} \mathrm{C}$ until further analysis. During ISO infusion, heart rate was kept under close observation by means of an ECG. When the heart rate increased by more than 30 beats/min above baseline or in case of an irregular heart rhythm, ISO infusion was stopped.

\section{Genetic analysis}

Genomic DNA was extracted from peripheral blood leukocytes by digestion with protein $\mathrm{K}$ followed by phenol/ chloroform extraction. Amplification of the relevant segments of the ADRB2 and GNB3 genes was performed by polymerase chain reaction (PCR) as previously described. ${ }^{16,35}$ PCR products were digested at $37^{\circ} \mathrm{C}$ for $1 \mathrm{~h}$ using $B s r \mathrm{DI}$, ItaI, MnlI or BseDI. The digested fragments were visualized using ethidium bromide staining and UV-transmitted light. Finally, we evaluated the accuracy of the restriction fragment length polymorphism (RFLP) method by direct sequencing of random samples and got 100\% agreement. In addition, two persons independently evaluated samples and identical results were obtained.

\section{Biochemical analysis}

Whole blood was collected in tubes containing ethylene diamine tetraacetic acid (EDTA) and centrifuged for $10 \mathrm{~min}$ at $3000 \mathrm{rpm}\left(4^{\circ} \mathrm{C}\right)$ and the plasma removed for the enzymatic calorimetric quantitation of FFA (NEFA C kit, Wako, Neuss, Germany) and glycerol (Boehringer, Mannheim, Germany) on a COBAS FARA centrifugal spectrometer (Roche Diagnostica). Standard samples with known concentrations were included in each run for quality control. 
Statistical analysis

All statistical calculations were performed with SPSS for Macintosh (version 11.0; SPSS Inc., Chicago, IL, USA). The initial statistical analysis, performed for the whole group $(n=108)$, indicated a significant gender effect for the Arg16 allele on lipolytic parameters (iAUC $\triangle \mathrm{FFA} P=0.01$, allelgender interaction) and fat oxidation (iAUC $\triangle \mathrm{RQ} P=0.042$ ). For this reason, the presented analysis is stratified by gender. The effect of genotypes on lipolytic responses and fat oxidation was investigated using analysis of variance (ANOVA) (adjusted for age and BMI). Post hoc testing was performed by Student's unpaired $t$-test with Bonferroni correction. Linkage disequilibrium was estimated according to Devlin et $a l .{ }^{37}$ Diplotype analysis were performed as described before. ${ }^{38,39}$ The goodness of fit between observed and expected genotype frequency (Hardy-Weinberg equilibrium, HWE) was statistically tested using the $\chi^{2}$-test. ${ }^{40}$ Allele and genotype frequency distributions for the whole group $(n=108)$ are presented in Table 2 . Energy expenditure (EE) was adjusted for FFM by means of covariance analysis (ANCOVA). The ISO-induced effect on fat oxidation (RQ), thermogenesis (EE) and lipolysis (FFA, glycerol) were expressed as incremental area under the curve (iAUC) above baseline, calculated according to the trapezium rule. All data are represented as mean \pm standard error of the mean (s.e.m.). $P<0.05$ was considered as statistically significant.

\section{Power calculation}

A power analysis was performed to estimate the sample size required enabling the accurate and reliable statistical judgments for the two-way parametric statistics. There are little or no published studies regarding the effect of ADRB2 and GNB3 gene variants and whole body lipolysis and fat oxidation, although the results of in vitro studies in human adipocytes support a major effect. We therefore estimated our sample size using published data of the effect of $\beta$ adrenergic stimulation on whole body lipolysis and fat oxidation. ${ }^{4,41,42}$ Power calculation indicated that to detect a difference in circulating FFA of $100 \mu \mathrm{mol} / 1$ (with an s.d. of $50 \mu \mathrm{mol} / \mathrm{l}$ ) or circulating glycerol of $50 \mu \mathrm{mol} / 1$ (with an s.d. of $25 \mu \mathrm{mol} / \mathrm{l})$ and a power of $0.80(\alpha=0.05$ and $\beta=0.20)$, the number of subjects in each group (two-tailed) should be 16 .

\section{Results}

As mentioned under statistical methods, initial analysis performed for the whole group $(n=108)$ indicated a significant gender effect for the Arg16 allele. For this reason, the presented analysis is stratified by gender.

\section{Subjects}

Anthropometric and metabolic characteristics of the study subjects are shown in Table 1 . Women had significantly higher percentage body fat, a lower waist-hip ratio and were significantly younger compared with male participants. Additionally, women had a significantly higher fasting FFA level. No significant differences were observed for BMI, resting $\mathrm{EE}$ (adjusted for $\mathrm{FFM}$ ) and fasting glycerol levels between genders.

Effect of codon 16 and 27 of the $\beta_{2}$-adrenoceptor gene (ADRB2) on fat oxidation and lipolysis after $\beta$-adrenergic stimulation Allele and genotype frequency distributions for the ADRB2 gene are shown in Table 2. For women, ANOVA analysis

Table 1 Subject characteristics

\begin{tabular}{lccc}
\hline & Men $(\mathrm{n}=65)$ & Women $(\mathrm{n}=43)$ & P-value \\
\hline Age (year) & $43.3 \pm 1.0$ & $38.8 \pm 1.3$ & * \\
BMI $\left(\mathrm{kg} / \mathrm{m}^{2}\right)$ & $32.5 \pm 0.5$ & $32.3 \pm 0.6$ & $\mathrm{NS}$ \\
$\%$ body fat & $31.7 \pm 0.7$ & $42.4 \pm 0.7$ & $* *$ \\
WHR & $1.04 \pm 0.01$ & $0.86 \pm 0.02$ & $* *$ \\
EE resting $(\mathrm{kJ} / \mathrm{min}) \#$ & $5.56 \pm 0.10$ & $5.72 \pm 0.13$ & $\mathrm{NS}$ \\
RQ resting & $0.81 \pm 0.01$ & $0.82 \pm 0.01$ & $\mathrm{NS}$ \\
Fasting FFA $(\mu \mathrm{mol} / \mathrm{l})$ & $477 \pm 27$ & $607 \pm 30$ & $* *$ \\
Fasting glycerol $(\mu \mathrm{mol} / \mathrm{l})$ & $73 \pm 3$ & $77 \pm 7$ & $\mathrm{NS}$
\end{tabular}

All values are means \pm s.e.m. Abbreviations: $B M I$, body mass index; $E E$, energy expenditure; FFA, free fatty acids; RQ, respiratory quotient; WHR, waist-to-hip ratio;,. \# EE, adjusted for FFM. ${ }^{*} P=0.01,{ }^{* *} P<0.001$ men vs women using Student's unpaired $t$-test.

Table 2 Allele, genotype and diplotype frequency distributions of the ADRB2 gene and GNB3 gene polymorphisms

\begin{tabular}{ll}
\hline & $\mathrm{n}=108$ \\
\hline Allele frequency & \\
Arg16 & 0.394 \\
Gln27 & 0.569 \\
Thr164 & 0.972 \\
C & 0.741 \\
& \\
Genotype frequency & \\
Gly16Gly (wt) & 0.371 \\
Arg16Gly & 0.472 \\
Arg16Arg & 0.157 \\
Gln27Gln (wt) & 0.352 \\
Gln27Glu & 0.435 \\
Glu27Glu & 0.213 \\
Thr164Thr (wt) & 0.944 \\
Thr164lle & 0.056 \\
Ile164lle & 0 \\
CC & 0.537 \\
CT & 0.407 \\
TT & 0.055 \\
Diplotype frequency & \\
Gly16Gly/Glu27Glu & \\
Gly16Gly/Gln27Gln & \\
Arg16Arg/Gln27Gln & 0.185 \\
\hline
\end{tabular}

Alleles, genotypes and diplotypes are presented as decimals. All SNPs were in HWE. Abbreviations: Arg, arginine; Gln, glutamic acid; Glu, glutamine; Gly, glycine; lle, isoleucine; Thr, threonine; wt, wild type. 
indicated a significant genotype effect for codon 16 and a blunted increase in FFA $(P=0.046$, see Figure 1$)$, glycerol $(P=0.037$, see Figure 1$)$ and fat oxidation $(P=0.042$, see Figure 2), even after correction for age and BMI. Post hoc analysis indicated that in women the Arg16Gly genotype was significantly associated with a blunted increase in circulating FFA (iAUC $\triangle$ FFA after ISO: $379 \pm 35$ vs $493 \pm 40 \mu \mathrm{mol} / \mathrm{l}, P=0.041$, see Figure 1 ) and glycerol (iAUC $\Delta$ Glycerol after ISO: $86 \pm 11$ vs $128 \pm 14 \mu \mathrm{mol} / 1, P=0.026$, see Figure 1) during stimulation compared with female Gly16 homozygotes. In addition to a blunted lipolytic response, female Arg16Gly heterozygotes showed a blunted increase in
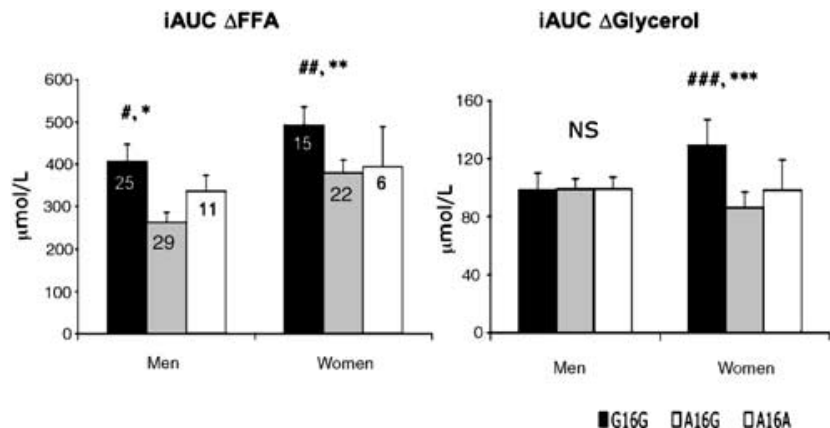

Figure 1 Lipolytic response for codon 16 polymorphisms of the ADRB2 gene. All values are means \pm s.e.m. iAUC $\triangle F F A$, iAUC $\Delta$ glycerol: incremental area under the curve for circulating free fatty acid (FFA) or glycerol concentration during $\beta$-adrenergic stimulation. G16G: Gly16Gly (black bar), A16G: Arg16Gly (gray bar), A16A: Arg16Arg (white bar). ANOVA (adjusted for

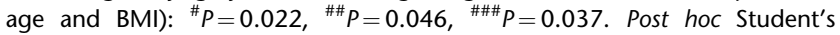
unpaired $t$-test: ${ }^{*} P=0.005,{ }^{*} P=0.041,{ }^{\star * *} P=0.026$ A16G vs G16G. Number of subjects in each group is indicated in the bars.

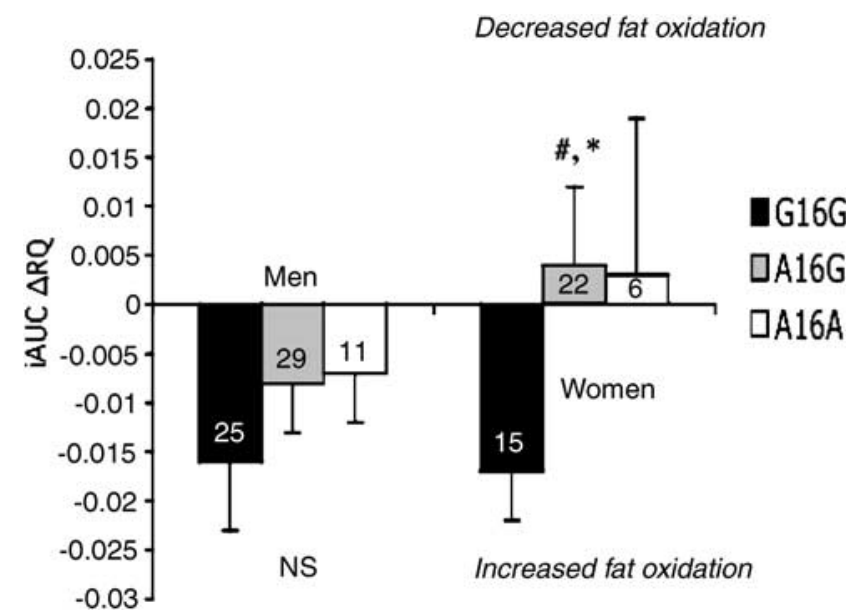

Figure 2 Fat oxidation for codon 16 polymorphisms of the ADRB2 gene. All values are means \pm s.e.m. iAUC $\triangle R Q$ : Incremental area under the curve for delta respiratory quotient (RQ) during $\beta$-adrenergic stimulation. G16G: Gly16Gly (black bar), A16G: Arg16Gly (gray bar), A16A: Arg16Arg (white bar). ANOVA (adjusted for age and BMI): ${ }^{\#} P=0.042$. Post hoc Student's unpaired t-test: ${ }^{*} P=0.043 \mathrm{G} 16 \mathrm{G}$ vs $\mathrm{A} 16 \mathrm{G}$. Number of subjects in each group is indicated in the bars. fat oxidation compared with Gly16 homozygotes (iAUC $\triangle \mathrm{RQ}$ after ISO: $0.004 \pm 0.007$ vs $-0.017 \pm 0.008, P=0.043$, see Figure 2) and a comparable thermogenic response (iAUC $\Delta$ EE after ISO: $0.51 \pm 0.07$ vs $0.70 \pm 0.09 \mathrm{~kJ} / \mathrm{min}$, NS).

Because lipolytic response and fat oxidation appeared to be reduced in both Arg16Gly and Arg16Arg carriers, Arg16 heterozygotes and homozygotes were combined into one group (Arg16Gly + Arg16Arg). Female Arg carriers (Arg16Gly + Arg16Arg) appeared to have a blunted increase in circulating FFA $(382 \pm 31$ vs $493 \pm 43 \mu \mathrm{mol} / 1, \quad P=0.042)$ and glycerol $(89 \pm 10$ vs $129 \pm 18 \mu \mathrm{mol} / 1, P=0.038)$ after $\beta$-adrenergic stimulation compared with Gly16Gly homozygotes. This altered lipolytic response in female Arg carriers (Arg16Gly + Arg16Arg) was accompanied by a decreased fat oxidation after stimulation (iAUC $\triangle \mathrm{RQ}$ after ISO $0.003 \pm 0.007$ vs $-0.016 \pm 0.005, P=0.024)$. No differences were found in ISO-induced thermogenesis (iAUC $\triangle \mathrm{EE}$ after ISO: $0.57 \pm 0.07$ vs $0.70 \pm 0.09 \mathrm{~kJ} / \mathrm{min}$, NS), body weight, BMI and other anthropometric variables.

Data in male overweight subjects were less consistent: ANOVA analysis (adjusted for age and BMI) indicated only a significant genotype effect of codon 16 and a blunted increase in FFA $(P=0.022$, see Figure 1$)$. Post hoc analysis revealed that male carriers of the Arg16Gly genotype had a significantly blunted increase in circulating FFA during $\beta$ adrenergic stimulation compared with male Gly16 homozygotes, (266 \pm 30 vs $401 \pm 34 \mu \mathrm{mol} / \mathrm{l}, P=0.005$; see Figure 1 ). However, this blunted FFA response was not accompanied by a blunted increase in circulating glycerol (see Figure 1) nor a decreased fat oxidation (iAUC $\Delta R Q$, see Figure 2). Furthermore, taking Arg16 heterozygotes and homozygotes together into one group, (Arg16Gly + Arg16Arg) carriers showed a blunted increase in circulating FFA $(281 \pm 21$ vs $406 \pm 41 \mu \mathrm{mol} / \mathrm{l}, P=0.004)$ compared with Gly16Gly carriers, whereas ISO-induced changes in glycerol, thermogenesis and RQ were comparable between groups. Again, no differences were found in body weight, BMI and other anthropometric variables.

For neither female nor male subjects associations were found between genetic variation in codon 27 and 164 of the $\beta_{2}$-adrenoceptor gene (ADRB2) and alterations in fat oxidation or lipolytic response during $\beta$-adrenergic stimulation.

\section{Diplotype analysis}

Three homozygous and functional diplotypes were investigated in both male and female subjects: Gly16Gly/Glu27Glu, Arg16Arg/Gln27Gln and Gly16Gly/Gln27Gln. The diplotype frequency distribution is depicted in Table 2 . From the 55 men carrying the Gly16 allele, 47 also carried the Glu27 allele $\left(\chi^{2}=32.653, P<0.0001\right)$, indicating linkage disequilibrium $\left(\left|D^{\prime \prime}\right|=0.854, r^{2}=0.494\right) .{ }^{37}$ In $21.5 \%(n=14)$ of the men and $14 \%(n=6)$ of the women, the Gly16Gly/Glu27Glu diplotype was apparent. This diplotype was not associated with a decreased lipolytic response (iAUC $\triangle F F A$ and iAUC $\Delta$ glycerol) or fat oxidation (iAUC $\Delta R Q$ ) in male or female 
subjects. Nevertheless, female carriers $(n=6)$ of the Gly16Gly/Glu27Glu diplotype had lower fasting FFA levels $(431 \pm 49$ vs $636 \pm 32 \mu \mathrm{mol} / 1, P<0.05)$ compared with female non-carriers $(n=37)$. No differences were found in body weight, BMI and other anthropometric variables. The other two diplotypes (Arg16Arg/Gln27Gln and Gly16Gly/ Gln27Gln) were also not associated with an altered fat oxidation, thermogenic or lipolytic response in this population. Owing to the relatively low sample size, we were not able to identify $\beta_{2}$-adrenoceptor haplotypes for codons 16 , 27 and 164 with a frequency $>5 \%$.

Effect of the C825T polymorphism in exon 10 of the $G$ protein beta-3 subunit (GNB3) gene on fat oxidation and lipolysis Allele and genotype frequency distributions for the GNB3 gene are shown in Table 2 . Male TT carriers $(n=4)$ showed a tendency toward a blunted increase in circulating FFA (iAUC $\Delta$ FFA after ISO: $173 \pm 46$ vs $435 \pm 32 \mu \mathrm{mol} / \mathrm{l}$ ) and glycerol (iAUC $\Delta$ Glycerol after ISO: $47 \pm 14$ vs $107 \pm 8 \mu \mathrm{mol} / \mathrm{l}$ ) after $\beta$-adrenergic stimulation compared with CT carriers $(n=29)$. Similar results were obtained for male CC carriers $(n=32)$. Unfortunately, the number of subjects in the TT group $(n=4)$ were too small to perform statistical analysis. In female overweight subjects, no associations were found for the C825T polymorphism and an altered lipolytic response, thermogenesis or fat oxidation.

\section{Discussion}

To the best of our knowledge, this is the first study to investigate the association between genetic variability in the $A D R B 2$ gene and GNB3 gene and in vivo lipolysis and fat oxidation in overweight and obese men and women.

The major findings of our study are as follows: firstly, genetic variability in codon 16 of the ADRB2 gene was associated with a blunted increase in circulating FFA and glycerol during $\beta$-adrenergic stimulation with the nonselective ISO in female subjects. In male subjects, codon 16 was associated with a blunted ISO-induced increase in FFA, whereas no difference in glycerol was apparent. In female subjects, this blunted lipolytic response was also accompanied with a reduced fat oxidation. Finally, the TT genotype of the GNB3 gene was associated with a blunted increase in FFA and glycerol in male subjects. This blunted lipolytic response was not accompanied by a reduced fat oxidation.

Large et al. ${ }^{16}$ showed that the Arg16Gly genotype was associated with an in vitro fivefold increase in agonist sensitivity of the $\beta_{2}$-adrenoceptor in abdominal subcutaneous adipocytes of overweight female subjects, without any significant effect on glycerol release. In our study, the Arg16 allele was associated with blunted ISO-induced responses in FFA, glycerol and fat oxidation (iAUC $\triangle \mathrm{RQ}$ ) in women and a blunted increase in FFA in men. The reason for this apparent discrepancy with our findings may be related to the differences in our in vivo vs the in vitro approach to study lipolysis. In the in vitro situation, in vivo factors like the neuroendocrine environment and local adipocyte blood flow are not taken into account. In addition, the majority of in vitro studies are performed on adipocytes derived from the subcutaneous region in both genders. It should be mentioned that there are major differences in catecholamine-induced lipolysis between depots (subcutaneous vs visceral and gluteofemoral) and also gender differences in body fat distribution. ${ }^{43-45}$ Our data indicate that variability in codon 16 of the $A D R B 2$ gene may contribute to a reduced in vivo $\beta$-adrenoceptor-mediated lipolysis and fat oxidation, ${ }^{1-4}$ indicating that these blunted responses may be important primary factors in obesity.

Besides looking at individual codons, we also studied the effect of diplotypes. We chose to study two common ( $>10 \%$ in the population) and one less common $(<5 \%)$ homozygous combination (Gly16Gly/Glu27Glu, Arg16Arg/ Gln27Gln and Gly16Gly/Gln27Gln), as they have been reported to have a significant effect on lipolysis. ${ }^{38}$ In addition, these SNPs belong to the same pathway and transfection experiments showed that they are functional. ${ }^{39}$ Finally, in our population, as has been reported before, there is strong linkage disequilibrium between codons 16 and $27 .{ }^{46}$ Nevertheless, no effect of diplotypes on lipolytic, thermogenic response or fat oxidation was found in our study. Only the Gly16Gly/Glu27Glu diplotype was associated with a lower fasting FFA concentration in female overweight subjects, which may possibly reflect a reduced rate of lipolysis in subcutaneous adipose tissue. ${ }^{47}$ Finally, literature suggests that the Thr164Ile $\beta_{2}$-adrenoceptor polymorphism is closely associated with Gly at position 16 and Gln at position 27. ${ }^{39,48}$ Nevertheless, due to the relatively low sample size, we were not able to identify $\beta_{2}$-adrenoceptor haplotypes for codons 16,27 and 164 with a frequency $>5 \% .^{38}$

The observed genotype frequency for the polymorphism in the GNB3 gene was similar to that previously reported in other Caucasian populations. ${ }^{26,31}$ Rydén et al. ${ }^{35}$ showed that the $\mathrm{T}$ variant of this polymorphism was associated with a blunted in vitro responsiveness for the non-selective ISO in abdominal subcutaneous adipocytes of male and female overweight subjects. In contrast with Ryden et al. ${ }^{35}$ we found a tendency toward a reduced lipolysis aney in male overweight subjects. It should be mentioned that our sample has no adequate power to provide a conclusive result about a genotype effect for the C825T polymorphism in the GNB3 gene. Thus, further studies are necessary to confirm our in vivo findings in a larger population.

In summary, variation in codon 16 of the $A D R B 2$ gene is associated with an impaired lipolytic response in male and female overweight and obese subjects and by a blunted fat oxidation in overweight and obese women. In conclusion, the present results suggest that genetic variability in the $A D R B 2$ gene influences lipolysis regulation in vivo in overweight and obese subjects and that this is subject to gene- 
gender interactions. This indicates that genetic variability in the $A D R B 2$ gene may be an important factor in the development or progression of obesity and obesity-related disorders.

\section{Acknowledgements}

This study was supported by a research grant from The Netherlands Association for Scientific Research (NWO) to EE Blaak and Swedish Research Council to P Arner.

\section{References}

1 Blaak EE, Van Baak MA, Kemerink GJ, Pakbiers MT, Heidendal GA, Saris WH. Beta-adrenergic stimulation of skeletal muscle metabolism in relation to weight reduction in obese men. Am J Physiol 1994; 267 (2 Part 1): E316-E322.

2 Blaak EE, Saris WH, Wolffenbuttel BH. Substrate utilization and thermogenic responses to beta-adrenergic stimulation in obese subjects with NIDDM. Int J Obes Relat Metab Disord 1999; 23: 411-418.

3 Blaak EE, van Aggel-Leijssen DP, Wagenmakers AJ, Saris WH, van Baak MA. Impaired oxidation of plasma-derived fatty acids in type 2 diabetic subjects during moderate-intensity exercise. Diabetes 2000; 49: 2102-2107.

4 Blaak EE, Van Baak MA, Kemerink GJ, Pakbiers MT, Heidendal GA, Saris WH. Beta-adrenergic stimulation of energy expenditure and forearm skeletal muscle metabolism in lean and obese men. Am J Physiol 1994; 267 (2 Part 1): E306-E315.

5 Schiffelers SL, Blaak EE, Baarends EM, Van Baak MA, Saris WH, Wouters EF et al. Beta-adrenoceptor-mediated thermogenesis and lipolysis in patients with chronic obstructive pulmonary disease. Am J Physiol Endocrinol Metab 2001; 280: E357-E364.

6 Reynisdottir S, Wahrenberg H, Carlstrom K, Rossner S, Arner P. Catecholamine resistance in fat cells of women with upper body obesity due to decreased expression of beta 2 -adrenoceptors. Diabetologia 1994; 37: 428-435.

7 Kobilka BK, MacGregor C, Daniel K, Kobilka TS, Caron MG, Lefkowitz RJ. Functional activity and regulation of human beta 2adrenergic receptors expressed in Xenopus oocytes. J Biol Chem 1987; 262: 15796-15802.

8 Kobilka BK, Frielle T, Dohlman HG, Bolanowski MA, Dixon RA, Keller P et al. Delineation of the intronless nature of the genes for the human and hamster beta 2-adrenergic receptor and their putative promoter regions. I Biol Chem 1987; 262: 7321-7327.

9 Liggett SB. Pharmacogenetics of beta-1- and beta-2-adrenergic receptors. Pharmacology 2000; 61: 167-173.

10 Leineweber K, Brodde OE. Beta2-adrenoceptor polymorphisms: relation between in vitro and in vivo phenotypes. Life Sci 2004; 74: 2803-2814.

11 Green SA, Turki J, Innis M, Liggett SB. Amino-terminal polymorphisms of the human beta 2-adrenergic receptor impart distinct agonist-promoted regulatory properties. Biochemistry 1994; 33: 9414-9419.

12 Bengtsson K, Orho-Melander $\mathrm{M}$, Melander O, Lindblad U, Ranstam J, Rastam L et al. Beta(2)-adrenergic receptor gene variation and hypertension in subjects with type 2 diabetes. Hypertension 2001; 37: 1303-1308.

13 Kim SH, Kim DJ, Seo IA, Min YK, Lee MS, Kim KW et al. Significance of beta2-adrenergic receptor gene polymorphism in obesity and type 2 diabetes mellitus in Korean subjects. Metabolism 2002; 51: 833-837.

14 Iwamoto N, Ogawa Y, Kajihara S, Hisatomi A, Yasutake T, Yoshimura $\mathrm{T}$ et al. Gln27Glu beta2-adrenergic receptor variant is associated with hypertriglyceridemia and the development of fatty liver. Clin Chim Acta 2001; 314: 85-91.

15 Ukkola O, Rankinen T, Weisnagel SJ, Sun G, Perusse L, Chagnon $\mathrm{YC}$ et al. Interactions among the alpha2-, beta2-, and beta3-adrenergic receptor genes and obesity-related phenotypes in the Quebec family study. Metabolism 2000; 49: $1063-1070$.

16 Large V, Hellstrom L, Reynisdottir S, Lonnqvist F, Eriksson P, Lannfelt L et al. Human beta-2 adrenoceptor gene polymorphisms are highly frequent in obesity and associate with altered adipocyte beta-2 adrenoceptor function. J Clin Invest 1997; 100: 3005-3013.

17 Hellstrom L, Large V, Reynisdottir S, Wahrenberg H, Arner P. The different effects of a Gln27Glu beta 2-adrenoceptor gene polymorphism on obesity in males and in females. J Intern Med 1999; 245: 253-259.

18 Meirhaeghe A, Helbecque N, Cottel D, Amouyel P. Impact of polymorphisms of the human beta2-adrenoceptor gene on obesity in a French population. Int $J$ Obes Relat Metab Disord 2000; 24: 382-387.

19 Meirhaeghe A, Helbecque N, Cottel D, Amouyel P. Beta2adrenoceptor gene polymorphism, body weight, and physical activity. Lancet 1999; 353: 896.

20 Mori Y, Kim-Motoyama H, Ito Y, Katakura T, Yasuda K, IshiyamaShigemoto $\mathrm{S}$ et al. The Gln27Glu beta2-adrenergic receptor variant is associated with obesity due to subcutaneous fat accumulation in Japanese men. Biochem Biophys Res Commun 1999; 258: 138-140.

21 Ishiyama-Shigemoto S, Yamada K, Yuan X, Ichikawa F, Nonaka K. Association of polymorphisms in the beta2-adrenergic receptor gene with obesity, hypertriglyceridaemia, and diabetes mellitus. Diabetologia 1999; 42: 98-101.

22 Oomen JM, van Rossum CT, Hoebee B, Saris WH, van Baak MA. Beta2-adrenergic receptor polymorphisms and salbutamolstimulated energy expenditure. J Clin Endocrinol Metab 2005; 90: 2301-2307.

23 Green SA, Cole G, Jacinto M, Innis M, Liggett SB. A polymorphism of the human beta 2-adrenergic receptor within the fourth transmembrane domain alters ligand binding and functional properties of the receptor. J Biol Chem 1993; 268: 23116-23121.

24 Green SA, Rathz DA, Schuster AJ, Liggett SB. The Ile164 beta(2)adrenoceptor polymorphism alters salmeterol exosite binding and conventional agonist coupling to G(s). Eur J Pharmacol 2001; 421: 141-147.

25 Hoffstedt J, Iliadou A, Pedersen NL, Schalling M, Arner P. The effect of the beta(2) adrenoceptor gene Thr164Ile polymorphism on human adipose tissue lipolytic function. Br J Pharmacol 2001; 133: 708-712.

26 Siffert W, Rosskopf D, Siffert G, Busch S, Moritz A, Erbel R et al. Association of a human G-protein beta3 subunit variant with hypertension. Nat Genet 1998; 18: 45-48.

27 Patten JL, Johns DR, Valle D, Eil C, Gruppuso PA, Steele G et al. Mutation in the gene encoding the stimulatory $G$ protein of adenylate cyclase in Albright's hereditary osteodystrophy. N Engl J Med 1990; 322: 1412-1419.

28 Carel JC, Le Stunff C, Condamine L, Mallet E, Chaussain JL, Adnot $\mathrm{P}$ et al. Resistance to the lipolytic action of epinephrine: a new feature of protein Gs deficiency. J Clin Endocrinol Metab 1999; 84: 4127-4131.

29 Schunkert H, Hense HW, Doring A, Riegger GA, Siffert W. Association between a polymorphism in the $G$ protein beta3 subunit gene and lower renin and elevated diastolic blood pressure levels. Hypertension 1998; 32: 510-513.

30 Benjafield AV, Jeyasingam CL, Nyholt DR, Griffiths LR, Morris BJ. G-protein beta3 subunit gene (GNB3) variant in causation of essential hypertension. Hypertension 1998; 32: 1094-1097.

31 Siffert W, Forster P, Jockel KH, Mvere DA, Brinkmann B, Naber C et al. Worldwide ethnic distribution of the $\mathrm{G}$ protein beta3 
subunit $825 \mathrm{~T}$ allele and its association with obesity in Caucasian, Chinese, and Black African individuals. J Am Soc Nephrol 1999; 10: 1921-1930.

32 Dong Y, Zhu H, Wang X, Dalageorgou C, Carter N, Spector TD et al. Obesity reveals an association between blood pressure and the G-protein beta3-subunit gene: a study of female dizygotic twins. Pharmacogenetics 2004; 14: 419-427.

33 Hauner H, Meier M, Jockel KH, Frey UH, Siffert W. Prediction of successful weight reduction under sibutramine therapy through genotyping of the G-protein beta3 subunit gene (GNB3) C825T polymorphism. Pharmacogenetics 2003; 13: 453-459.

34 Hegele RA, Anderson C, Young TK, Connelly PW. G-protein beta3 subunit gene splice variant and body fat distribution in Nunavut Inuit. Genome Res 1999; 9: 972-977.

35 Ryden M, Faulds G, Hoffstedt J, Wennlund A, Arner P. Effect of the $(\mathrm{C} 825 \mathrm{~T}) \mathrm{Gbeta}(3)$ polymorphism on adrenoceptor-mediated lipolysis in human fat cells. Diabetes 2002; 51: 1601-1608.

36 Siri WE. The gross composition of the body. Adv Biol Med Phys 1956; 4: 239-280.

37 Devlin B, Risch N. A comparison of linkage disequilibrium measures for fine-scale mapping. Genomics 1995; 29: 311-322.

38 Eriksson P, Dahlman I, Ryden M, Hoffstedt J, Arner P. Relationship between beta-2 adrenoceptor gene haplotypes and adipocyte lipolysis in women. Int J Obes Relat Metab Disord 2004; 28: 185-190.

39 Drysdale CM, McGraw DW, Stack CB, Stephens JC, Judson RS Nandabalan $\mathrm{K}$ et al. Complex promoter and coding region beta 2 -adrenergic receptor haplotypes alter receptor expression and predict in vivo responsiveness. Proc Natl Acad Sci USA 2000; 97: 10483-10488.

40 Schaid DJ, Jacobsen SJ. Biased tests of association: comparisons of allele frequencies when departing from Hardy-Weinberg proportions. Am J Epidemiol 1999; 149: 706-711.

41 Blaak EE, van Baak MA, Saris WH. Beta-adrenergically stimulated fat oxidation is diminished in middle-aged compared to young subjects. J Clin Endocrinol Metab 1999; 84: 3764-3769.

42 Kanaley JA, Cryer PE, Jensen MD. Fatty acid kinetic responses to exercise. Effects of obesity, body fat distribution, and energyrestricted diet. J Clin Invest 1993; 92: 255-261.

43 Blaak E. Gender differences in fat metabolism. Curr Opin Clin Nutr Metab Care 2001; 4: 499-502.

44 Arner P. Catecholamine-induced lipolysis in obesity. Int J Obes Relat Metab Disord 1999; 23 (Suppl 1): 10-13.

45 Blaak EE, Schiffelers SL, Saris WH, Mensink M, Kooi ME. Impaired beta-adrenergically mediated lipolysis in skeletal muscle of obese subjects. Diabetologia 2004; 47: 1462-1468.

46 Dallongeville J, Helbecque N, Cottel D, Amouyel P, Meirhaeghe A. The Gly16->Arg16 and Gln27-> Glu27 polymorphisms of beta2-adrenergic receptor are associated with metabolic syndrome in men. J Clin Endocrinol Metab 2003; 88: 4862-4866.

47 Hagstrom-Toft E, Bolinder J, Ungerstedt U, Arner P. A circadian rhythm in lipid mobilization which is altered in IDDM. Diabetologia 1997; 40: 1070-1078.

48 Bruck H, Leineweber K, Buscher R, Ulrich A, Radke J, Insel PA et al. The Gln27Glu beta2-adrenoceptor polymorphism slows the onset of desensitization of cardiac functional responses in vivo. Pharmacogenetics 2003; 13: 59-66. 